REVISTA 89.2

Revista RELACIONES INTERNACIONALES

Escuela de Relaciones Internacionales.

Universidad Nacional, Costa Rica.

N.o 89.2 • Julio-Diciembre de 2016

doi: http://dx.doi.org/10.15359/ri.89-2.1

Pp. $17-46$

\title{
LA OFENSIVA DE BOLIVIA Y CHILE Y LA DIPLOMACIA PÚBLICA MEDIADA
}

BOLIVIA AND CHILE ON THE OFFENSIVE VIA MEDIATED PUBLIC DIPLOMACY

\author{
Daniel Aguirre Azócar* \\ Juan Cristóbal Villalobos***
}

\section{RESUMEN:}

El presente artículo aborda las recientes acciones comunicacionales de Bolivia y Chile en el marco de la diplomacia pública. A partir de un análisis de contenido de intervenciones en espacios mediáticos-digitales, se presentan los alcances de acciones cruzadas considerando las perspectivas de estudios representativos en la materia. Así, al examinar las intervenciones de ambos países contrastan y comparan acciones de diplomacia pública frente a los escenarios de discordia referente a la demanda boliviana ante la Corte Internacional de Justicia. Para concluir, se expone, a modo tentativo, una evaluación de la diplomacia pública efectuada por cada parte, evidenciando elementos que restan y restringen una agenda de futuro entre ambas naciones.

Palabras claves: La Haya, Bolivia-Chile, diplomacia pública, medios, digital.

\begin{abstract}
:
This article focuses on recent messaging initiatives by Bolivia and Chile within the context of public diplomacy. By means of a content analysis of messaging efforts via media platforms, it expects to ascertain the breadth and scope of competing views guided by representative literature on the subject. Moreover, by analyzing social media usage of both countries, the article will compare and contrast public diplomacy initiatives as they pertain to the Bolivian case against Chile at the International Court of Justice. In ending, the study's expected outcomes include a tentative evaluation of each side's public diplomacy actions. In addition, the final analysis should provide evidence pointing toward elements that further restrict a positive shared agenda for both countries in the foreseeable future.
\end{abstract}

Keywords: The Hague, Bolivia-Chile, Public Diplomacy, Media, Digital.

\footnotetext{
* Académico de la Universidad del Pacífico en Santiago, Chile. Correo electrónico: d.aguirre@uchile.cl.

** Socio de Vanguardia Comunicación en Santiago, Chile. Correo electrónico: jvillalobos@vanguardiacomunicacion.cl.
} 
Recientemente, el ministro de Relaciones Exteriores de Chile, Heraldo Muñoz, en una entrevista radial del 5 de agosto de 2016, sentenció que las relaciones con Bolivia "están en su punto más bajo de los últimos 100 años" blemente, con dos demandas presentadas en la Corte Internacional de Justicia de La Haya, una interpuesta por el gobierno boliviano en abril 2013 y otra presentada por Chile durante el mes de junio 2016, se agudizan las tensiones entre Santiago y La Paz. La demanda por acceso al Océano Pacífico por parte de Bolivia y la demanda por reconocer el cauce internacional de las aguas del Silala han activado en la elite gobernante de ambos países una situación de alerta y de preocupación. Como consecuencia, las acciones comunicacionales desplegadas por ambas naciones han tenido como objetivo presentar y proponer perspectivas cruzadas sobre la legitimidad de los argumentos de cada una. Estas perspectivas se han materializado en una serie de comunicaciones que, en el transcurso de los últimos meses, ha escalado a niveles de virulencia y de confrontación rara vez visto en el sistema internacional actual.

En este escenario de desencuentro y de estrategias comunicacionales de ataque, el presente artículo examinará si el mecanismo de proyección internacional denominado diplomacia pública aplica para describir las acciones de Chile y Bolivia en el espacio digital. Para determinar dicha interrogante, se propone examinar la confección y posibles alcances de la presentación de material comunicacional específicamente en videos disponibles online en la plataforma YouTube. Para apoyar el análisis se utiliza la visión constructivista de la teoría de las relaciones internacionales para caracterizar las acciones en el contexto y sopesar las implicancias futuras para la relación bilateral en la arena política internacional. Finalmente, el artículo argumentará que los mensajes de ambos gobiernos presentan aspectos que conceptualmente se acercan con dificultad a los objetivos y directrices de diplomacia pública, concluyendo que al desconsiderar estrategias de relacionamiento propiciados y apoyados a través de los preceptos de la diplomacia pública, es altamente probable que la relación no madure ni prospere a horizontes de mayor entendimiento.

Consecuentemente, el artículo que sigue se divide en cuatro secciones. Primero se conceptualiza con base en definiciones referentes y recientes de la diplomacia pública, al considerar los objetivos que esta debería perseguir. Así también se especifica la aplicación de la diplomacia pública en el espacio mediático y digital. Segundo, se contextualiza describiendo los recientes acontecimientos y concentrando el análisis en la demanda por una salida al Océano Pacífico. En la tercera parte se incorpora la perspectiva wendtiana del constructivismo, lo

1 La entrevista radial completa en Tele13 Radio está disponible en http://www.t13.cl/radio/mesa-central/noticia/canciller-munoz-obstaculo-pueblos-chile-y-bolivia-es-gobierno-boliviano, recuperado el 15 de agosto de 2016. 
cual brinda un marco de interpretación para caracterizar las acciones comunicacionales a partir de las culturas de anarquía que dicho teórico ha propuesto. Finalmente, en la última sección, se describen y analizan dos videos publicados en la web que combinan los marcos conceptuales de la diplomacia pública y del constructivismo de las relaciones internacionales.

\section{Diplomacia pública: Pensamiento y acción internacionalista}

A fines de la Segunda Guerra Mundial y durante el desarrollo de la Guerra Fría surge la conceptualización concreta del mecanismo de influencia internacional denominado por el exdiplomático y exdecano de la Universidad de Tufts, Edmund Gullion, como diplomacia pública (Cull, 2008). Durante el transcurso de la Guerra Fría, la utilización de dicho mecanismo fue ampliamente desplegado por Estados Unidos con la premisa de "ganar los corazones y las mentes" de individuos que vivían bajo la "cortina de hierro". Tras el colapso del Muro de Berlín y, posteriormente al desmoronamiento de la Unión Soviética, en palabras de Fukuyama constituyen "el fin de la historia", en el sentido de que la victoria de una ideología política por sobre otra se materializó por completo (1989). Desde algunas perspectivas se argumenta que dicha victoria fue alcanzada en parte debido al uso estratégico de herramientas de comunicación; particularmente los medios de comunicación del Estado contribuyeron a la implosión del modelo soviético ${ }^{2}$. Consecuentemente, personal diplomático y académico ha inferido que los medios de comunicación, en conjunto con la conceptualización e implementación del mecanismo de diplomacia pública, podrían cumplir, en los asuntos internacionales, con el objetivo de persuadir para influir en la opinión pública internacional (Gullion,1965).

No obstante, la diplomacia pública es un concepto complejo de aprehender y operacionalizar como práctica. En efecto, debido a la decena de definiciones, variados alcances y aplicaciones, suele ser difícil acercarse a una sola forma de comprenderla y abordarla. Sin embargo, una definición específica e inicial a nuestro juicio es proponerla como "un proceso gubernamental en el cual éste se comunica con públicos en otros países para poder propiciar un entendimiento acerca de las ideas, ideales, instituciones y cultura, como así también se puedan valorar los objetivos y políticas actuales del país [que comunica]” (Tuch, 1990, p. 3).

Actualmente, la diplomacia pública por un buen tiempo ha sufrido de pocas fuentes teóricas referenciales que guíen e informen a quienes tratan

2 Un ejemplo de dicho periodo que se cita reiteradamente es la radio Voice of America.

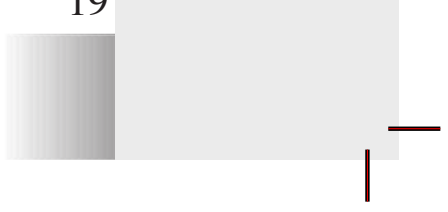


de utilizarla o estudiarla (Gilboa, 2008). Por lo general, la diplomacia pública recurre a nociones del poder blando de acuerdo con la definición del politólogo internacionalista, Joseph Nye Jr. (1990, 2008), para quien, el poder blando en relación con la diplomacia pública consiste en tener un arsenal de recursos de valores culturales y políticos, además de tener políticas internacionales que otros países del mundo consideren suficientemente atractivas para apoyarlas (2008). Entonces, la diplomacia pública se puede entender como mecanismo para persuadir e influenciar a otros en el mundo, vinculada a los recursos de poder blando intrínsecos del país que busca comunicase hacia otros para así recibir adhesión de los públicos extranjeros.

Por otra parte, conceptualizaciones más precisas de la diplomacia pública desde otra mirada especifican el concepto . Tomando como base el pensamiento de Entman $(2004,2008)$, la diplomacia pública mediada (DPM) es toda acción relacionada con el despliegue del mecanismo de diplomacia pública a través de medios tradicionales de comunicación como así también -a nuestro parecer- los medios digitales, incluyendo las redes sociales. Por tanto, al considerar un análisis a partir de las acciones en el espacio digital es posible comprender la utilización de la diplomacia pública como proyección del poder blando a través de los medios de comunicación y su potencial impacto en públicos de otros países.

Ahora bien, a diferencia de estudios más generales de la diplomacia pública en la región, escasean estudios previos en cuanto a DPM relacionados con naciones de América Latina ${ }^{3}$. La gran mayoría de los estudios de similares características se enfocan principalmente en países como Estados Unidos, países de la Unión Europea y China. Efectivamente, la DPM como campo de estudio ha tenido principalmente un desarrollo a partir de Robert Entman y los trabajos recientes de Guy Golan del 2013, 2014 y Golan y Lukito 2015, pero ninguno de estos o similares toman casos de estudio latinoamericanos. En consecuencia, dada la falta de estudios de DPM en la región, el estudio espera contribuir y avanzar en la reflexión de esta temática, especialmente teniendo presentes las implicancias políticas que afectan el futuro devenir de la relación bilateral de Chile y Bolivia.

Por consiguiente, considerando el marco referencial sobre la diplomacia pública

3 La Revista Mexicana de Política Exterior dedicó un número (85) en el año 2009 a la diplomacia pública desde una mirada conceptual y cultural. Por otra parte, algunos estudios brasileños sobre el poder blando y en el contexto del BRICS existen. Así también, se encontró un trabajo que aborda la diplomacia pública colombiana y un interesante artículo sobre la diplomacia pública cubana realizada a través de sus médicos en Venezuela. Un ejemplo de artículo que aborda parcialmente la diplomacia pública de Chile es el de Jiménez-Martínez (2013). Chile’s Quest to Improve its Image Abroad. Finalmente, Méndez-Coto (2015) presenta un primer acercamiento comparado entre Brasil, Chile, México y Perú sobre el estado de implementación de acciones de diplomacia pública e imagen país. 
y la diplomacia pública mediada en particular, el análisis de la DPM de Bolivia y Chile, referente a temáticas críticas y actuales que convocan a ambas naciones, se propone utilizar una herramienta de análisis para examinar acciones en redes sociales, particularmente en cuanto al uso de videos online en YouTube. Para acercarnos a dicho objetivo nos planteamos las siguientes preguntas de investigación que guían este trabajo:

P1. El contenido de los videos oficiales en YouTube de ambos gobiernos, ¿puede ser considerado diplomacia pública mediada?

P2. ¿A qué público está dirigido cada video analizado?

P3. ¿Qué aspectos de la producción y la presentación de los videos le pueden parecer convincentes al potencial público objetivo del video?

\section{Abordaje metodológico y muestra}

En términos de cómo se realiza el análisis, se plantea un abordaje metodológico que contempla un proceso inductivo basado en un instrumento de análisis de contenido creado por los autores con base en las definiciones sobre la DPM. Asimismo, para ordenar sistemáticamente el análisis, se apoya y estructura el instrumento a partir de la metodología visual de Rose (2013). Los elementos para el análisis de contenido propuestos por Rose consideran tres sitios y tres modalidades para estructurar el ejercicio analítico (2013, pp. 19-30). Los sitios, según lo que se intenta representar, son: producción, la imagen misma, y audienciar. La idea del esquema de "sitios" apunta a dividir el elemento visual en el entendido de que, en cada sitio, lo que se quiere mostrar (o representar) tiene un momento de análisis. Es decir, el sitio de producción implica entender cómo la representación del mensaje fue preparada para el consumo de la audiencia. Así. también, la imagen misma implica entender qué es lo que la representación potencialmente intenta comunicar. Y finalmente el sitio de audienciar implica tomar en cuenta cómo el sujeto consumidor del contenido resignifica el mensaje en la representación visual -a veces aceptando el mensaje o incluso rechazándolo-. Cabe señalar que nuestro análisis se abocará a entender los primeros dos sitios de representación, es decir la producción y la imagen misma. El sitio de audienciar queda al margen, debido a las dificultades de conseguir y dimensionar el impacto en quienes han visto los videos que son analizados.

Por otra parte, la metodología propuesta por Rose también comprende ponderar las modalidades de cada sitio de representación y la autora sugiere considerar modalidades, como dimensiones adicionales. Las tres modalidades son: lo técnico, la

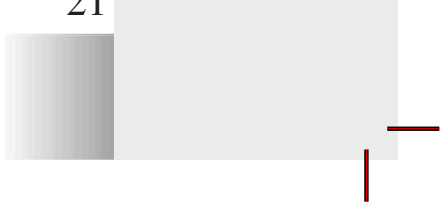


composición y lo social. Para nuestro análisis integrado, incluimos, en la modalidad social, las variables correspondientes a la diplomacia pública mediada con dos criterios. Así la herramienta de análisis se grafica como aparece en la tabla 1:

\section{Tabla 1}

Esquema analítico

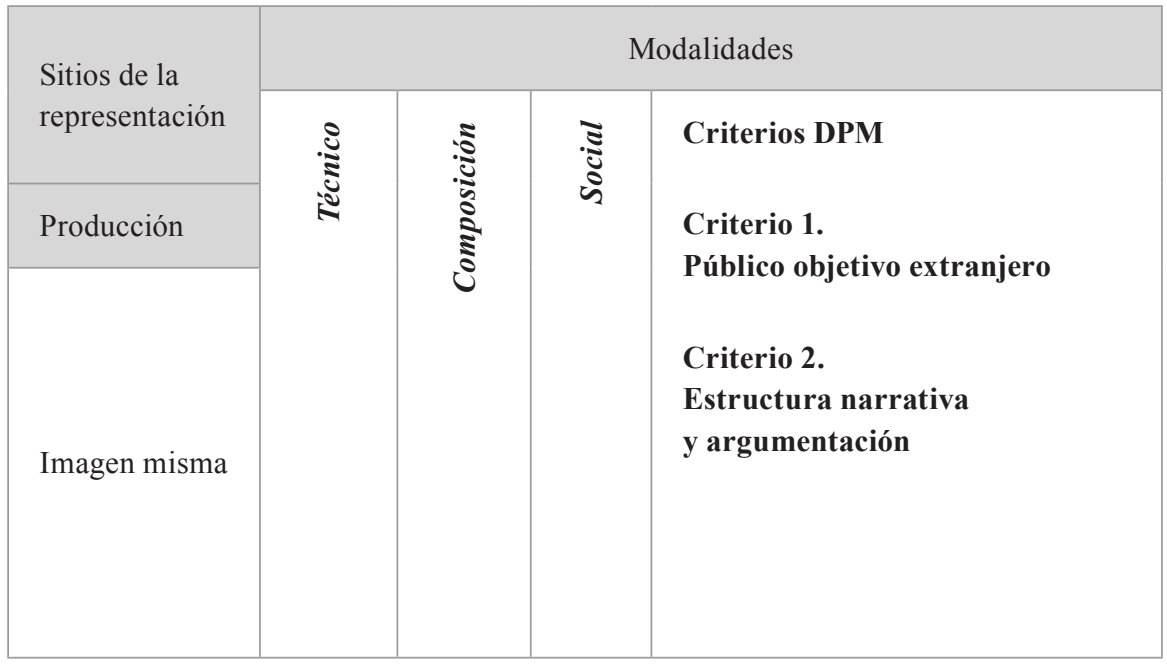

Nota: Confección de los autores.

\section{Criterios de análisis de DPM}

Dentro de la modalidad social de la representación en los videos examinados y con la guía de las definiciones de la diplomacia pública mediada se utilizaron los siguientes criterios de análisis.

Criterio 1. Público objetivo extranjero

Criterio 2. Estructura narrativa y argumentación

Finalmente, en cuanto a la muestra de videos se analizan dos videos en total a partir de una selección deliberada que, como criterio principal, tiene que ver 
con la temática de la demanda boliviana. Asimismo, se definió, como otro requisito, que los videos estén disponibles en YouTube o una plataforma similar. Finalmente, se intentó encontrar videos lo más parecido posible para efectos de comparación. Los videos son los que aparecen en la tabla 2:

\section{Tabla 2}

Videos analizados

\begin{tabular}{|l|l|}
\hline \multicolumn{2}{|c|}{ Autor, título, Fecha de publicación y vistos (Views) - revisado el 17 de agosto, 2016 } \\
\hline $\begin{array}{l}\text { Gobierno de Chile: } \\
\text { "Chile y la aspiración marítima bolivia- } \\
\text { na: Mitos y realidad." } \\
2 \text { de octubre } 2014\end{array}$ & $\begin{array}{l}\text { ATB Red Nacional: } \\
\text { "Video del mar." }\end{array}$ \\
\hline Vistos: 301.458 & Vistos:63.332 diciembre 2014 \\
\hline $\begin{array}{l}\text { Nota: Se publica una versión doblada al } \\
\text { idioma inglés con } 7.039 \text { vistos. }\end{array}$ & $\begin{array}{l}\text { Nota: El Ministerio de Comunicación de } \\
\text { Bolivia publica un video titulado } \\
\text { "Voces para el mar." } 27 \text { de marzo } 2016 . \\
\text { Tiene 1.538 vistos. }\end{array}$ \\
\hline
\end{tabular}

\section{Culturas de anarquía e identidades de la relación bilateral}

A la fecha, las relaciones bilaterales entre Chile y Bolivia siguen siendo caracterizadas por la enemistad y carencia extensa de cooperación e interdependencia; a diferencia de casos entre otras diadas en el subsistema sudamericano, tales como Argentina-Chile y recientemente Perú-Chile. Es decir, la relación Bolivia-Chile es una de competencia y de rivalidad, que se evidencia y refleja, además, en el plano de la retórica y la comunicación política. Como consecuencia, persiste una conflictividad situada en una lógica competitiva que comienza a fines del siglo XIX y que sigue definiendo el horizonte estratégico y la agenda de política exterior de cada parte con respecto a la otra.

Dada tal situación, y como se ha delimitado la interacción entre los gobiernos de La Paz y Santiago, referente al tema altamente sensible del denominado enclaustramiento boliviano y el derecho de tener legítimo y soberano acceso al Pacífico, la lógica de relacionamiento entre las partes ha propiciado un estancamiento altamente improbable de superar en el corto a mediano plazo. La de-

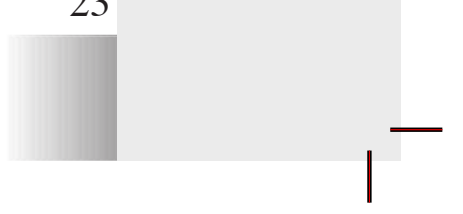


manda boliviana y, recientemente, la demanda chilena sobre las aguas del Silala brindan ejemplos para comprender la escalada reciente reflejada en los medios de comunicación masivos y sociales en el contexto sudamericano.

Por tanto, para comprender dicha escalada de acciones y de uso de los medios de comunicación, pareciera necesario presentar e incorporar estos elementos de análisis para ayudar a entender acción con base en las identidades de agentes considerando las lógicas de interacción definidas conceptualmente por Alexander Wendt (1999) como culturas de anarquía.

Las culturas de anarquía, según Wendt son tres y las importancia de estas radica en que permiten entender acciones y el relacionamiento con otros Estados en el sistema internacional, a partir de las ideas que guían el accionar de cada Estado actor (o agente). Estas culturas son: la hobbesiana, la lockeana y la kantiana, las cuales caben en un continuo que ayuda a caracterizar temporalmente el estado de la situación de relacionamiento entre actores y las ideas que apoyan y definen las identidades-roles entre las partes (tabla 3).

Tabla 3

Culturas de anarquía según la perspectiva de Wendt

\begin{tabular}{|l|l|}
\hline \multicolumn{1}{|c|}{ Cultura } & \multicolumn{1}{c|}{ En relación con la otra cultura } \\
\hline Hobbesiana & Enemigas - la existencia soberana no es reconocida. \\
\hline Lockeana & $\begin{array}{l}\text { Rivales - reconocen la existencia de la otra con base en la so- } \\
\text { beranía. }\end{array}$ \\
\hline Kantiana & $\begin{array}{l}\text { Amigas - reconocen la existencia de la otra cultura y se rigen } \\
\text { por dos reglas: el orden mundial se mantiene sin violencia y por } \\
\text { medio de apoyo mutuo. }\end{array}$ \\
\hline
\end{tabular}

Nota: Traducido y adaptado de Lacassagne (2012).

Ahora bien, incorporar la tipificación de lógicas de relacionamiento en el sistema internacional según la perspectiva constructivista no es algo del todo novedoso, pero sí útil al momento de abordar un análisis que permita examinar y determinar el comportamiento de países entre sí. Por otro lado, realizar un acercamiento como el desarrollado en este trabajo podría permitir comprender 
el comportamiento referente al uso de los medios de comunicación a nivel internacional aplicado a las acciones de diplomacia pública mediada de Bolivia y Chile. Así, se sugiere que la incorporación del factor comunicacional a través de la diplomacia pública mediada puede ser relevante y novedosa a ponderar en este caso $^{4}$.

Consecuentemente, nuestra aproximación al análisis se orienta desde la mirada del constructivismo aplicado a nuestros objetos de estudio que son dinámicos por ser inherentemente sociales y políticos. A modo de ilustración proponemos una aplicación esquemática de la relación Bolivia-Chile para determinar aspectos de las culturas de anarquía e identidades en el contexto de esta relación bilateral (tabla 4). Determinar, entonces, es evidenciar culturas de anarquía e identidades en juego y presentes en el análisis de los videos mencionados.

Tabla 4

Culturas de anarquía entre Chile y Bolivia 2014-2016

\begin{tabular}{|c|c|c|}
\hline Cultura - Identidad & Chile & Bolivia \\
\hline Hobbesiana - Enemigos & $\begin{array}{l}\text { No aplica ya que se } \\
\text { reconoce como Estado } \\
\text { soberano que integra el } \\
\text { sistema internacional. }\end{array}$ & $\begin{array}{l}\text { No aplica ya que se } \\
\text { reconoce como Estado } \\
\text { soberano que integra el } \\
\text { sistema internacional. }\end{array}$ \\
\hline Lockeana - Rivales & $\begin{array}{c}\text { Se reconoce soberanía } \\
\text { nacional según costumbre y } \\
\text { Tratado } 1904 .\end{array}$ & $\begin{array}{l}\text { Se reconoce soberanía } \\
\text { nacional, exceptuando } \\
\text { territorio previamente } \\
\text { boliviano y recursos natu- } \\
\text { rales hídricos en disputa. }\end{array}$ \\
\hline Kantiana - Amigos & $\begin{array}{l}\text { No se evidencia amistad, } \\
\text { pero sí respeto por el orden } \\
\text { mundial de no violencia. } \\
\text { El apoyo mutuo para la } \\
\text { supervivencia } \\
\text { es inexistente. }\end{array}$ & $\begin{array}{l}\text { No se evidencia amistad, } \\
\text { pero sí respeto por el orden } \\
\text { mundial de no violencia. } \\
\text { El apoyo mutuo para la } \\
\text { supervivencia } \\
\text { es inexistente. }\end{array}$ \\
\hline
\end{tabular}

Nota: Confección de los autores.

4 En el recientemente publicado libro Strategic Narratives; Communication and Power in the World Order de Miskimmon, A., O’Loughlin, B., \& Roselle, L. (2014), se incorporan perspectivas de las relaciones internacionales que guían el análisis del uso de narrativas en la diplomacia pública, con especial acento en el pensamiento de Alexander Wendt. 


\section{La relación Chile-Bolivia y la diplomacia pública mediada}

El 24 de abril del 2013, el canciller boliviano David Choquehuanca presentó, frente la Corte Internacional de Justicia de La Haya, una demanda ante el Estado chileno. Bolivia le exigía a la Corte que estableciera la obligación de Chile de negociar de "buena fe" un acuerdo que le otorgara una salida soberana al océano Pacífico.

Esta solicitud generó gran revuelo en ambos países, ya que, si bien esta es una aspiración histórica y ha sido un grave y permanente escollo en la relaciones entre ambos países (los que no tienen relaciones diplomáticas desde 1978), por primera vez esta disputa territorial llegaba a un tribunal internacional.

Desde que se presentó la demanda, la estrategia legal de Bolivia ha sido acompañada de una coordinada campaña interna y externa de explicación y difusión. El presidente Evo Morales ha sido su principal promotor a nivel mundial. Se ha reunido con los presidentes Françoise Holland, Angela Merkel, Vladimir Putin y el papa Francisco, entre otras autoridades. Sin bien, a excepción del jefe de la Iglesia Católica, ninguno ha apoyado explícitamente la petición altiplánica, Morales ha asegurado que los líderes internacionales la entienden y respaldan.

Otro actor clave en esta arremetida comunicacional ha sido el canciller Choquehuanca. Su rol, además de exponer la demanda ante las audiencias mundiales, ha incluido dos visitas "privadas" a Chile, con gran cobertura periodística. En la primera estuvo en Santiago y se reunió con grupos de izquierda y estudiantiles pro-causa boliviana, e incluso realizó una ceremonia indígena frente los medios de comunicación. Su segundo periplo consistió en una controvertida "inspección" a los puertos chilenos de Arica y Antofagasta. Esta, además de ser noticia en ambos países, logró cobertura en diarios de España, Ecuador, Colombia, Estados Unidos, Perú y Argentina. Algo inédito, ya que generalmente esta disputa limítrofe solo genera interés a nivel local.

\section{Con la fuerza de la razón - Chile}

Desde que Chile se vio enfrentado a la acción judicial de su vecino, su estrategia tanto judicial como política y comunicacional se ha sustentado en presentar argumentos jurídicos e históricos, lo que ha generado la crítica de varios sectores debido a su carácter hermético y sin elementos de cercanía o explicativos para la opinión pública, tanto nacional como nacional. 
Después de más de un año de presentada la demanda ante el Tribunal de La Haya, Chile lanzó este material audiovisual, cuyo mensaje central es que hoy el país altiplánico ya cuenta con un tránsito libre y privilegiado por puertos chilenos. Sobre esa base, el título del vídeo resume su fin principal: exponer la "realidad" y destruir los "mitos" sobre lo que significa para Bolivia no contar con soberanía marítima y explicar los "privilegios" que le otorga Chile.

Este video tiene dos ejes conductores: entregar datos e información histórica, técnica y legal, y transmitir la idea de que la posición del gobierno actual es respaldada por todos los sectores de la elite política nacional. Con ese fin, los argumentos se presentan a través de las palabras de la actual presidenta Michelle Bachelet (2006-2010, 2014-2018), de los expresidentes Sebastián Piñera (2010-2014), Ricardo Lagos (2000-2006), Eduardo Frei (1994-2000) y del canciller Heraldo Muñoz.

El material audiovisual parte explicando en qué consiste la aspiración boliviana, afirmando que este país busca que Chile ceda parte de su territorio para cumplir con su aspiración marítima. Esta introducción es acompañada de cuidadas imágenes de la costa en disputa, de las ciudades chilenas de Arica y Antofagasta, de un tren en medio del desierto y de un puerto con un activo movimiento de cargas. A medida que transcurre el video, queda claro que cada imagen tiene que ver con alguno de los argumentos que se expondrán a continuación.

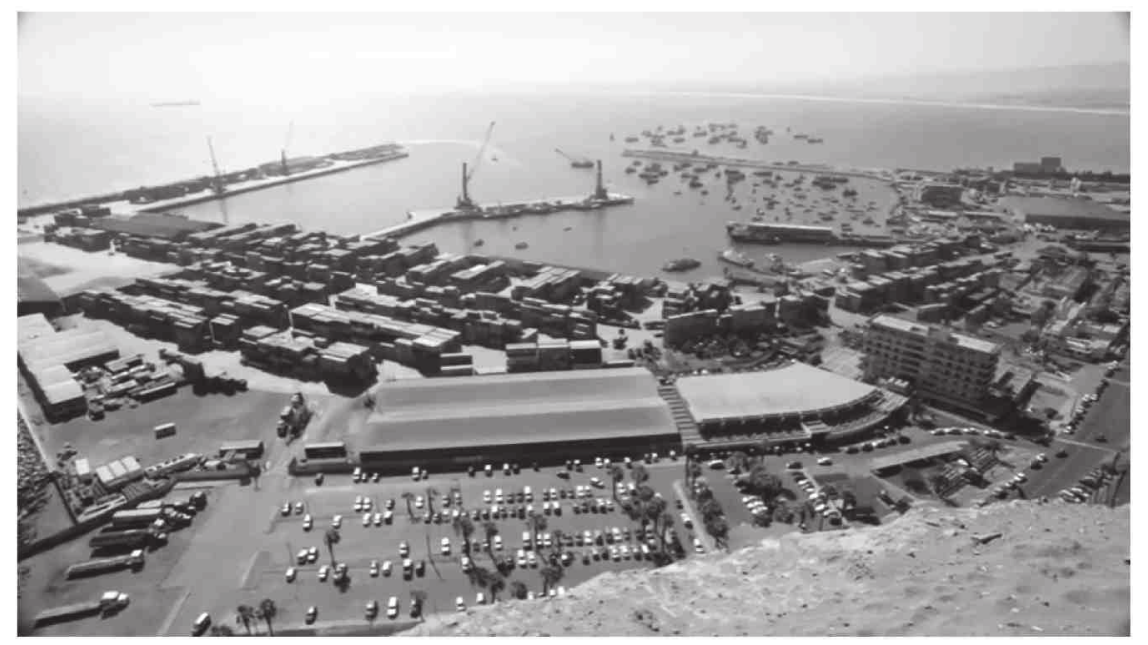

Chile y la aspiración marítima boliviana: mito y realidad

Figura 1. Chile y la aspiración marítima boliviana: mito y realidad

(Ministerio de Relaciones Exteriores de Chile, 2014).

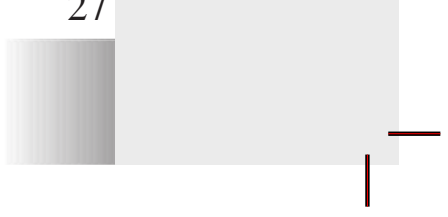


La voz en off del video (neutra y femenina que, si bien es cercana y agradable, también es firme y segura) acompañada de una suave y neutra música de fondo explica que Bolivia habla de una "supuesta" (el tono de voz enfatiza esta palabra) obligación de Chile de negociar, basándose en negociaciones realizadas en el pasado en la que autoridades chilenas se habrían manifestado dispuestas a ceder soberanía.

Luego, aparece una cuña del canciller chileno Heraldo Muñoz explicando que el tratado de 1904 (que fijó los nuevos límites entre ambos países, subscrito después de que Chile venciera a la Confederación Perú-Boliviana en la Guerra del Pacífico de 1879) ha estado vigente y ha sido respetado por ambas naciones desde entonces. En esta, la primera aparición de una autoridad chilena se fija el tono de los que serán todas las declaraciones presentadas en este video: la entrega de argumentos racionales, con una presentación formal y oficial. El canciller Muñoz, vestido de traje y con colores sobrios, aparece rodeado de libros en lo que se presume es su oficina. En estas imágenes destaca una bandera chilena en el fondo que, si bien sale desenfocada, está ubicada de tal forma que cumple un rol protagónico en la escena y es coherente con el mensaje que se entrega: esta es la postura unitaria del Estado de Chile.

La siguiente declaración reafirma este mensaje: es el expresidente Sebastián Piñera quien retoma las palabras de Muñoz y, siguiendo la misma idea expuesta por el canciller, explica que Chile se comprometió -y ha cumplido- a darle a Bolivia la más amplia, eterna y libre circulación por puertos chilenos. Para reformar este mensaje, en la pantalla aparecen las palabras "amplia, eterna y libre" en una tipografía fina y clara. Luego, Sebastián Piñera intenta transformar en un hecho objetivo su particular interpretación de los beneficios que le ha significado a Bolivia el libre tránsito por estos puertos. Explica que la cesión que realiza Chile les ha permitido a sus vecinos "desarrollar su comercio y relaciones con el resto del mundo". Afirma que Chile ha procurado que esto se haga de la manera "más normal posible". Todos argumentos cuestionados por los representantes del gobierno boliviano. 


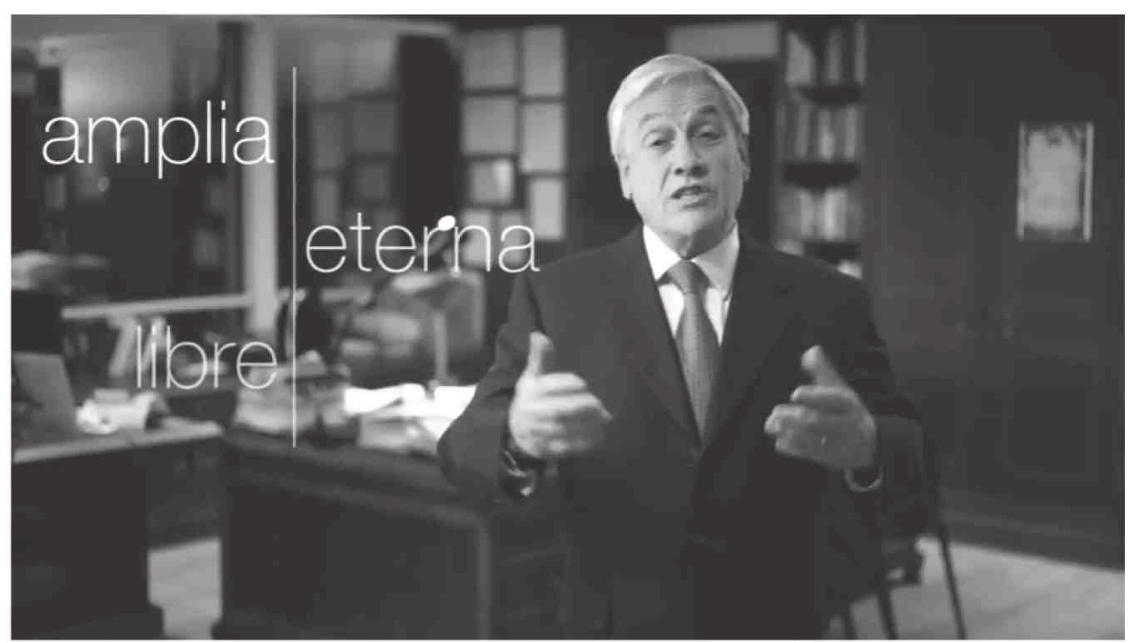

Chile y la aspiración marítima boliviana: mito y realidad

Figura 2. Chile y la aspiración marítima boliviana: mito y realidad (Ministerio de Relaciones Exteriores de Chile, 2014).

Antes del primer minuto del vídeo, ya se han expresado en forma clara y concisa dos de los mensajes centrales del relato chileno: durante más de un siglo el Tratado de 1904 ha sido respetado por ambos países y que Bolivia, gracias a Chile, cuenta con un acceso privilegiado al mar, lo que le ha significado múltiples beneficios económicos.

Al igual que Muñoz, Piñera aparece en su oficina, rodeado de libros y vestido con un traje y corbata de colores sobrios. Tanto en términos visuales como de discurso, hay una coherencia en la comunicación verbal y no verbal de ambos personeros. El video continúa con Muñoz que sigue la argumentación de Piñera y enfatiza que "en la práctica" Bolivia ya cuenta con acceso al mar a través de puertos chilenos y en "mejores condiciones" que las que poseen la mayoría de las naciones que no tienen salida al mar. Para darle relevancia a su mensaje, en la pantalla aparecen, con la misma tipografía empleada en las imágenes anteriores, la frase "Acceso al Mar".

Posteriormente, la voz femenina en off explica el uso que el pueblo boliviano hace de los puertos. Se recalca que son autoridades bolivianas y no chilenas quienes autorizan el despacho de las cargas y que es el país altiplánico el que dicta sus propios aranceles y tasas. Estos argumentos se acompañan con imágenes de la oficina de aduana y de grúas y camiones manejando containers en puertos que se ven modernos, eficientes y organizados.

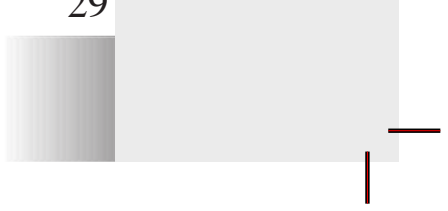


Después vuelve Muñoz y, aunque no lo dice directamente, arremete dando a entender que Chile accedió a las peticiones originales de Bolivia en cuanto al uso de puertos. Afirma que ese país escogió contar con salida por Arica y Antofagasta (esto acompañado por un didáctico mapa de la zona) y repite que el país altiplánico tiene potestad aduanera con agentes propios, libre tránsito para importación y exportación, y almacenamiento gratis. Privilegios que, según Muñoz, no gozan ni empresarios nacionales ni terceros países. Para hacer más dinámico el relato, se intercalan las imágenes del puerto con las del canciller.

Para reafirmar los "argumentos técnicos", a continuación se presenta el testimonio del encargado de asuntos portuarios y aduaneros de un puerto que no se especifica. La "autoridad técnica" habla con un cuidado fondo en el que, pese a lo difuminado de la imagen, se distingue el mar, un barco de carga y varios containers. Él explica que esta terminal portuaria está al servicio casi exclusivo de la carga boliviana y apoya sus argumentos con cifras; dice que de las 3 millones de toneladas que el 2014 pasaron por ese puerto, el 80\% fue carga boliviana. Para reforzar esa idea, se presentan esos números en la pantalla con llamativos colores.

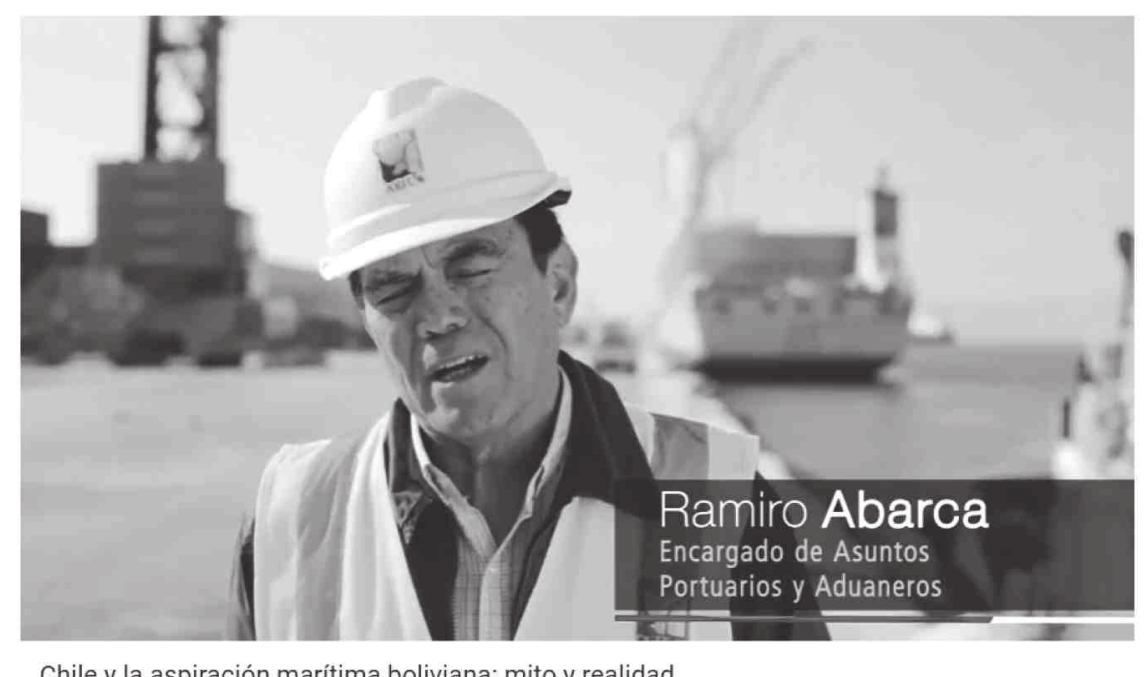

Figura 3. Chile y la aspiración marítima boliviana: mito y realidad (Ministerio de Relaciones Exteriores de Chile, 2014).

A continuación vuelve la voz femenina que, apoyada por imágenes de un tren, un camión en la carretera, un muelle portuario y barcos de carga en alta mar, enumera las "ventajas diferenciadoras concedidas por Chile", las que

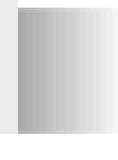


son expuestas con la gráfica característica en pantalla. Los mensajes que se entregan están basados en cifras y hechos concretos, destacándose que Bolivia tiene derecho al libre tránsito de su carga por territorio chileno, con total exención de impuestos. Según el video, la consecuencia lógica de estas "garantías" otorgadas por Chile es que más de siete mil empresas bolivianas actualmente comercian por sus puertos, un aumento, según sus datos, de un $132 \%$ en los últimos cinco años. Y para reformar las cifras, se recurre a la figura de otro expresidente chileno: Eduardo Frei Ruiz Tagle. Este habla desde un lugar que parece ser su casa, también vestido con unos sobrios traje y corbata, y con un fondo en que se distinguen libros, un verde jardín y la foto oficial de su padre, el expresidente Eduardo Frei Montalva (1964-1970) con la banda presidencial. Una vez más, los realizadores del video buscan transmitir una voz oficial, unitaria y con autoridad sobre los "privilegios" que Chile le otorga a Bolivia y sobre cómo este país se ha sido beneficiado. "Hay toda una infraestructura que Chile ha puesto a disposición de Bolivia", afirma categórico el expresidente Frei siguiendo la línea argumentativa expuesta hasta el momento. Todo esto, prosigue, pese a los cien millones de dólares anuales de costo para Chile. La voz en off vuelve a hablar de "beneficios y privilegios" de los que, según esta versión, disfrutaría Bolivia.

En el minuto 02 con 56 segundos se reitera la conclusión de la primera parte de este video: "Bolivia tiene acceso al mar".

Justo en la mitad del video, se produce un punto de inflexión y se pasa de los argumentos técnicos e históricos, a los de carácter más políticos y legales. Esta segunda parte comienza explicando que el Tratado de 1904 fijó los límites entre Bolivia y Chile. Luego el canciller Muñoz afirma que la política exterior de su país se basa en el respeto al derecho internacional y a los tratados limítrofes (implícitamente diciendo que Bolivia no lo hace). "Eso es lo que permite la estabilidad de las fronteras y las relaciones entre los Estados", enfatiza el ministro, mientras la frase "estabilidad de las fronteras" se resalta en pantalla.

Esto marca un giro en el discurso, puesto que ya no se le habla únicamente a un público que podría estar más interesado en las condiciones que tienen los grupos bolivianos para transitar por los puertos chilenos (lo que probablemente le preocupe más a las audiencias de Chile y Bolivia), sino que se emplea la lógica de la diplomacia pública y se contextualiza la demanda boliviana y se advierte a las elites y opinión pública internacional del "peligroso" precedente que se marcaría, si es que esta se acoge. "Supongamos que no respetáramos los tratados que se firmaron en Europa después de la Segunda y Primera Guerra Mundial. ¿Cómo serían las fronteras entre los países?, ¿Tendríamos que volver a los límites de comienzo del siglo XX? “, alerta Frei.

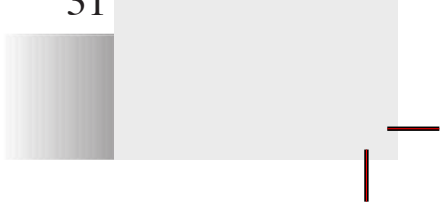


La misma idea la refuerza el expresidente Ricardo Lagos. También en su oficina con libros en el fondo y con corbata, pero sin chaqueta, afirma que se deben respetar los tratados suscritos libre y soberanamente por los países. "Libre y soberanamente" se destaca en la pantalla. Sin nombrar a Bolivia, Frei y Lagos acusan a este país de estar desconociendo un tratado que suscribió libremente. Luego, la voz en off enumera las concesiones de terreno que Chile le ha otorgado a Bolivia -que llegan a las 150 hectáreas-, explicado con mapas y gráficos. Se destaca especialmente la construcción del tren que une Arica con Alto de la Paz.

Retomando el carácter más político de los mensajes, aparece nuevamente el ex Presidente Sebastián Piñera, quien desvirtúa el argumento boliviano de que desde que se firmó el tratado de 1904, presidentes y diplomáticos chilenos han estado dispuestos a conceder un acceso soberano al Pacífico. Por primera vez se ataca directamente al país altiplánico y Piñera afirma que este pretende "que el simple hecho de que hayan existido conversaciones preliminares y de buena fe, generaría derechos y obligaciones aun cuando nunca se llegó a un acuerdo formal". El expresidente Lagos incluso va más allá y afirma que "la demanda de Bolivia no es contra Chile, sino que afecta a todo el sistema jurídico internacional. Si se acogiera la tesis boliviana, no habría ningún tratado seguro". Este mensaje alarmista, y que busca la comprensión y empatía internacional, se destaca al poner la frase "sistema jurídico internacional" en la pantalla.

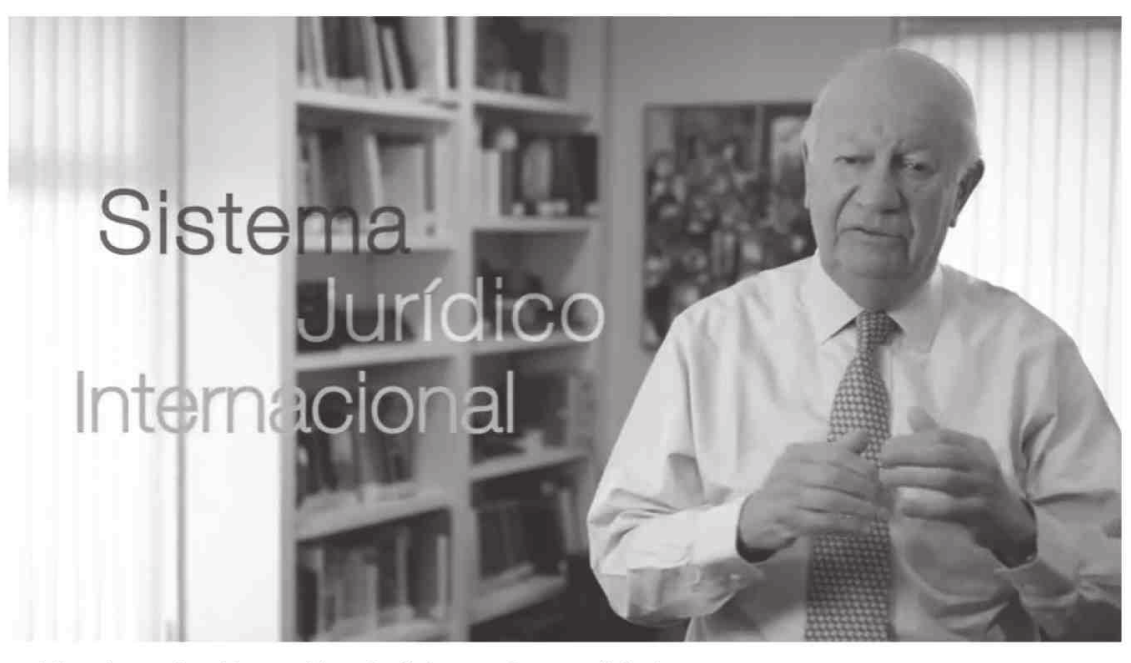

Chile y la aspiración marítima boliviana: mito y realidad

Figura 4. Chile y la aspiración marítima boliviana: mito y realidad (Ministerio de Relaciones Exteriores de Chile, 2014). 
En la tercera y última parte del video, se enfatiza el carácter de activo actor de Chile en el escenario latinoamericano y su aporte a la integración regional. De esta forma se busca contrarrestar la acusación de Bolivia - con la que muchos concuerdan en la región-, de que Chile es un país expansionista y sin "vocación latinoamericana".

En una serie de cuñas seguidas, Piñera, Frei, Lagos y Muñoz afirman que una mayor integración beneficiaría no solo a Bolivia, sino que a toda la región; y que eso ayudaría a superar los "temas del pasado".

El objetivo estratégico de que aparezcan el Canciller Muñoz y todos los presidentes chilenos vivos, es dar la imagen de continuidad de una política exterior de Estado.

Entendiendo eso, no sorprende que el video termine con las palabras de la presidenta Michelle Bachelet. Ella, desde la oficina presidencial y con la bandera chilena de fondo, reconoce que las relaciones entre ambos países han pasado por momentos difíciles, pero que hay que actuar "en el beneficio de nuestros pueblos". Aprovechando las habilidades blandas de la presidenta Bachelet, su reconocimiento internacional y su empatía, por primera vez se dejan los argumentos técnicos, jurídicos, históricos y políticos y se recalca el positivo impacto que la integración tendría en la ciudadanía de ambos países. La actual presidenta recalca que Chile está abierto al diálogo, pero lo circunscribe a "mejorar las condiciones que actualmente tiene Bolivia de acceso al mar, sin que eso signifique cesión de soberanía". Bachelet finaliza destacando dos mensajes que reafirman los conceptos con los que su país busca ser asociado por la comunidad internacional: que tiene vocación de paz y cooperación, y que está comprometido en crear una América Latina más unida e integrada.

El video termina con la imagen en cámara rápida de un hermoso atardecer en un puerto con un mar de fondo. El epílogo es claro: la aspiración de Bolivia de contar con acceso soberano al mar no tiene sustento ni justificación, porque ya cuenta con puertos modernos y eficientes con los cuales estar conectados con el mundo y surgir económicamente.

\section{Con la fuerza de la emoción - Bolivia}

A diferencia de "Mito y realidad", que se basa en argumentos racionales presentados como "objetivos" y factuales, el "Video del mar" se centra en la emoción y en la "justicia" de la causa boliviana. Para demostrar que la demanda ante el Tribunal de La Haya es una aspiración nacional, popular y fuertemente arraigada en el pueblo boliviano, los mensajes los entregan mujeres, jóvenes e indígenas anónimos, con quienes se busca representar la amplia diversidad

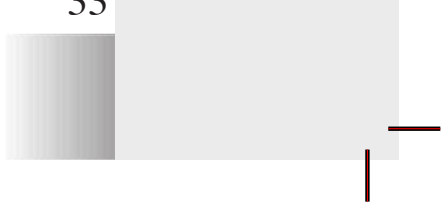


étnica y social de ese país. Aquí no exponen ministros ni presidentes; de hecho, ninguno de estos "representantes ciudadanos" aparece con nombre ni profesión. Se busca transmitir que estos no hablan simplemente como individuos, sino que como "representantes del pueblo" y que esta es una demanda transversal, no sola de una elite o gobierno de turno.

Tanto por el contenido y formato del "Video del mar", es claro que este fue elaborado para responder a su contraparte chilena. A diferencia de "Mito y realidad", este busca apelar a la empatía de un público más masivo y abierto a argumentos simples y emocionales.

El video parte con la voz en off clara y firme de un hombre con acento neutro, quien explica que "Bolivia es un estado pacifista y democrático, que tiene la legitimidad de un pueblo que ha decidido cambiar su destino y proyectarse al futuro", argumentación que se reafirma al aparecer escrita estas palabras sobre un fondo blanco con letras celestes. El mensaje implícito es que, si se logra un acceso soberano al mar, Bolivia podrá "cambiar su destino" y "proyectarse al futuro". Subyace la tesis de que el enclaustramiento marítimo es la causa de su subdesarrollo económico.

Este relato recoge una concepción bastante generalizada en la opinión pública internacional interesada en estos temas: que Bolivia es un país pobre y en vías de desarrollo en el que la inédita llegada al poder de un presidente indígena le ha dado protagonismo y voz a sectores tradicionalmente postergados en Latinoamérica. Chile, en cambio, es reconocido como una potencia regional que "hace bien las cosas", pero que está alejado de sus vecinos.

La siguiente cuña es de una mujer de unos treinta años, la que vestida con una camisa blanca y un manto celeste relata que, al surgir como nación independiente, su país contaba con $400 \mathrm{~km}$. lineales de costa y $120.000 \mathrm{~km} 2$ de litoral (esto se reafirma presentando esos mismos datos en la pantalla y con una tipografía con colores que hacen juego con la ropa de la mujer). Luego, un joven de unos veinte años explica que Bolivia perdió este territorio luego de la "invasión chilena" durante la Guerra del Pacífico de 1879, explicación apoyada por esa misma frase en la panta1la. Con una efectista mezcla de firmeza, rabia y tristeza, el joven arremete contra Chile y lo acusa de "invadir nuestro litoral con el único argumento de la violencia".

Esta idea es continuada por el testimonio de una mujer indígena de unos 40 años, quien vestida con un sobrero y manta indígena, asegura que Chile se ha beneficiado de una "gigantesca riqueza" (estas palabras se destacan sobre el fondo blanco) que superan los "supuestos" privilegios que los chilenos le han otorgado a su país. La mujer hace el típico gesto irónico con los dedos de "entre comillas" para resaltar lo de supuesto, lo que le da mayor dramatismo a su declaración. 


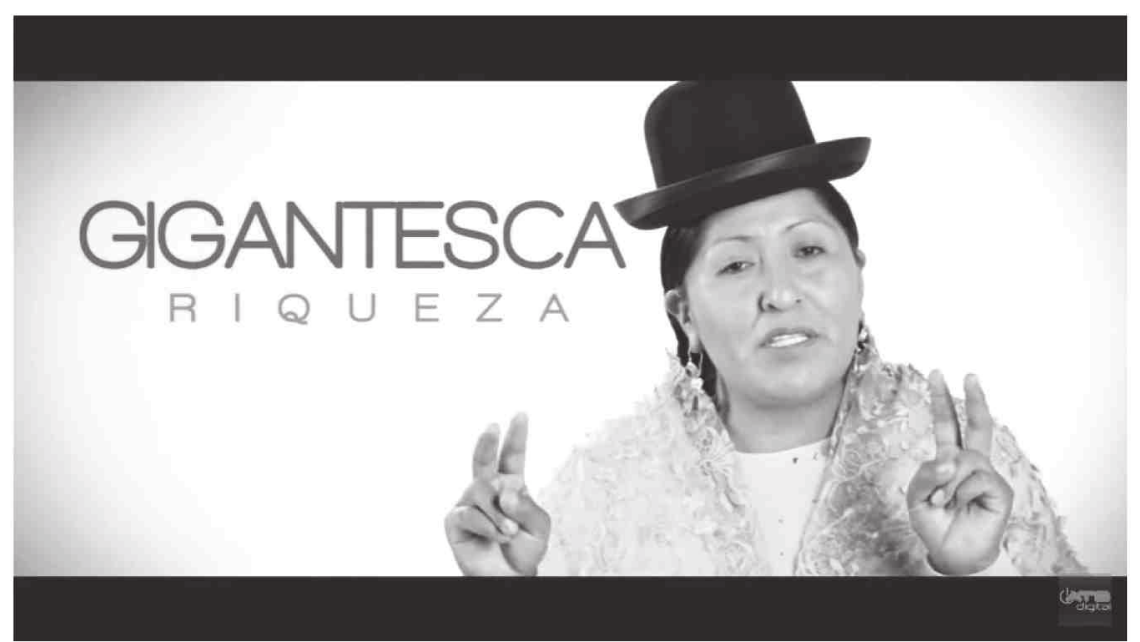

Demanda marítima de Bolivia ante la Corte Internacional de Justicia o "video del mar"

Figura 5. Demanda marítima de Bolivia ante la Corte Internacional de Justicia o "video del mar" (ATB Red Nacional, 2014).

A continuación, un joven veinteañero, con aros en ambas orejas y un pañuelo al cuello, entrega el otro argumento boliviano: desde 1904 varios diplomáticos, ministros de relaciones exteriores e incluso presidente chilenos se han comprometido a un acceso soberano al mar. "Muchas veces" se destaca en la pantalla. A continuación, la mujer indígena, con un marcado tono y expresión de indignación y frustración, afirma que "esos compromisos nunca fueron cumplidos".

Vuelve a aparecer la mujer que abre el video y asegura que "hemos tenido paciencia y buena fe por más de 100 años". A continuación, un hombre indígena de unos 50 años -vestido con un sombrero y camisa aimara- denuncia que ahora Chile tampoco pretende cumplir sus compromisos.

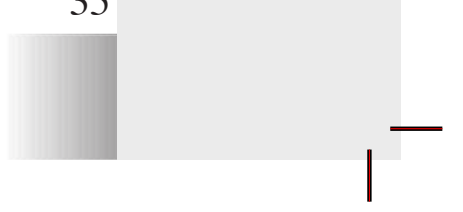




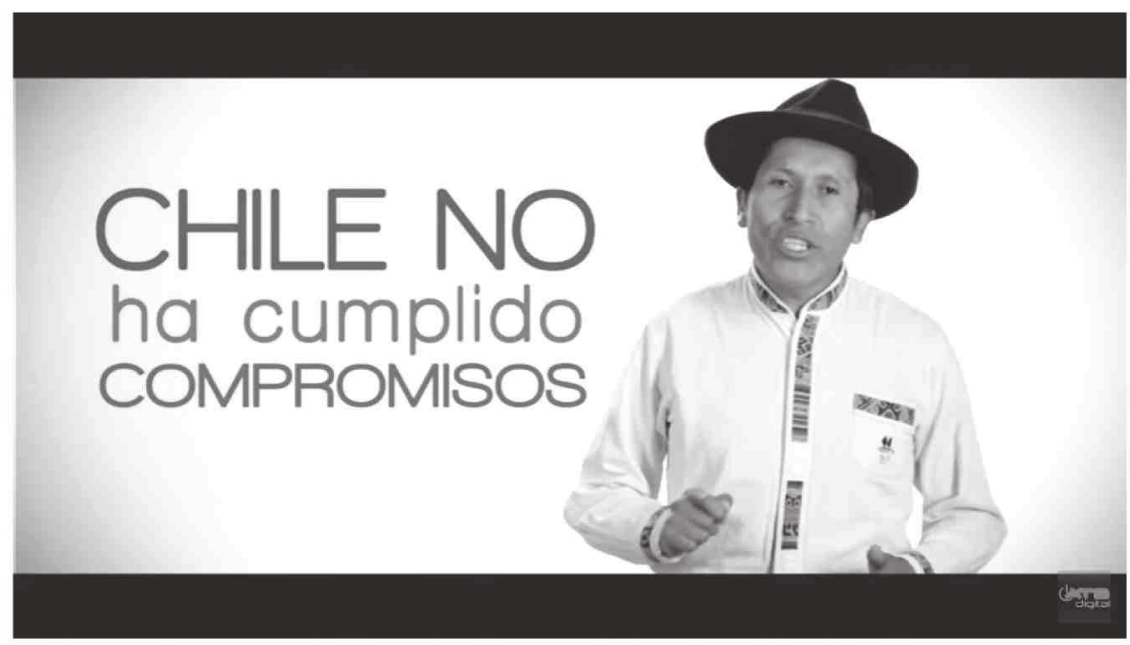

Demanda marítima de Bolivia ante la Corte Internacional de Justicia o "video del mar"

Figura 6. Demanda marítima de Bolivia ante la Corte Internacional de Justicia o "video del mar" (ATB Red Nacional, 2014).

Con argumentos emocionales, subjetivos y atractivos, pero que no presentan datos concretos como su contraparte chilena, el "Video del mar" va preparando el ambiente para justificar la demanda y ganar empatía y comprensión internacional.

Aquí se marca un punto de inflexión en la narración. Sobre la base de los argumentos anteriormente expuestos, aparece un joven que, a diferencia del resto, luce más formal vistiendo una chaqueta. Con solemnidad, afirma que "por (todo) eso", el "Estado plurinacional de Bolivia ha decidido demandar".

Esta explicación tiene un gran simbolismo político y comunicacional. El vocero boliviano dice que es el "Estado" quien ha decido emprender esta acción judicial, dejando en claro que esta no es únicamente una decisión del presidente Evo Morales o del canciller David Choquehuanca. Se habla de un "Estado plurinacional", es decir, uno que integra y respeta la diversidad de las distintas etnias; concepto muy atractivo y valorado por las audiencias internacionales progresistas, ya que representa una visión más moderna del Estado. Eso Chile no lo puede decir, especialmente por la permanente tensión que se vive en la sureña región de la Araucanía, donde se concentra el mayor porcentaje de indígenas, quienes denuncian discriminación y violencia de parte del Estado. 
Para destacar que Bolivia ha optado por la resolución no violenta del conflicto, se explica que el Tribunal de La Haya es la máxima instancia internacional para resolver conflictos internacionales en "forma pacífica".

Luego, bajo el enunciado "Qué pedimos", la siguiente vocera boliviana -una joven veinteañer- detalla la petición de su país: que se obligue a Chile a negociar y que este respete las promesas hechas en el pasado.

A continuación, la voz masculina en off da como ejemplo una nota oficial del Ministerio de Relaciones Exteriores chileno que en 1950 decía que su gobierno "está llano para entregar una salida soberana y propia al Océano Pacífico". Esa es la primera y única ocasión en que se entrega un dato concreto que puede complicar a su contraparte.

Posteriormente, prosiguen los "voceros del pueblo", los que van acusando a Chile de mentir y de "cambiar el escenario del debate". Se señala que la disputa no es sobre "libre tránsito" (como Chile lo trata de definir), sino que sobre soberanía (las palabras "Soberanía" y "Acceso Soberano al Mar" nuevamente se destacan en pantalla). Se explica que es necesario contar con un "puerto propio" para manejar sin restricciones el comercio exterior y volver a ser un "actor en el Océano Pacífico". Se puntualiza que "Bolivia no discute aranceles ni derecho de almacenajes", sino que "la soberanía que ha sido prometida en muchas oportunidades", desvirtuando el argumento chileno de que el libre acceso a los puertos zanja los problemas entre ambas naciones.

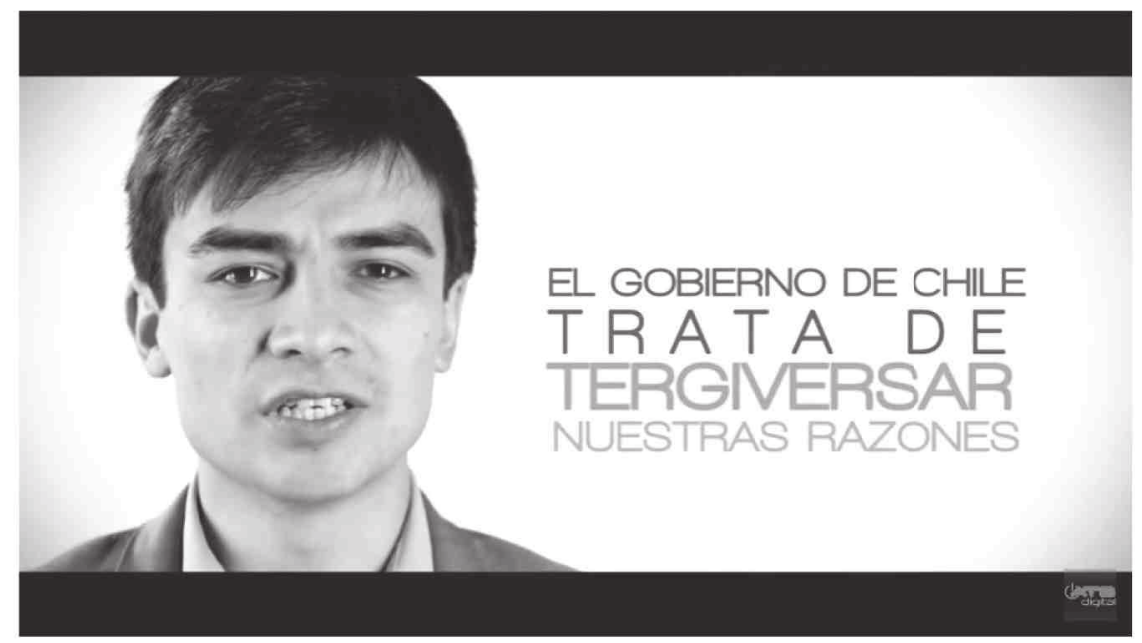

Demanda marítima de Bolivia ante la Corte Internacional de Justicia o "video del mar"

Figura 7. Demanda marítima de Bolivia ante la Corte Internacional de Justicia o "video del mar" (ATB Red Nacional, 2014). 
Según el video, el reciente desarrollo económico boliviano se debe "al proceso de transformación social y económico producto de la lucha de nuestro pueblo y de la exitosa gestión de nuestro gobierno en los últimos 10 años", dándole un espaldarazo a la administración de Evo Morales y desmintiendo la tesis chilena de que el libre acceso a los puertos ha ayudado al desarrollo comercial de su vecino.

Un joven con rasgos indígenas ironiza con los argumentos chilenos, afirmando con una sonrisa que "Chile es consciente de que el terreno que nos usurpó por la fuerza no se reparará con una línea férrea ni con facilidades de tránsito”.

A continuación, Bolivia va respondiendo una a una las acusaciones del video "Mito y realidad". Los "voceros ciudadanos" explican que su país respeta el Tratado de 1904 y que la demanda actual no se basa, "ni directa ni indirectamente", en este, y que es falso que Bolivia esté poniendo en riesgo el sistema internacional de justicia. Aquí, se da vuelta la crítica chilena convincentemente, ya que se afirma que Chile es el que no acepta a los tribunales internacionales. Postura que tiene bastante fuerza, ya que esta nación efectivamente cuestionó la competencia del Tribunal de La Haya para tratar esta disputa limítrofe, lo que fue rechazado por este organismo.

El "Video del mar" concluye que no hay forma más pacífica ni más democrática para resolver este conflicto que aceptar la jurisdicción del máximo tribunal internacional. Aquí se reafirman dos de las ideas centrales del relato: que este es un tema "de justicia" y que "hay asuntos pendientes" entre ambas naciones. Al igual que en el video chileno, su símil concluye haciendo un llamado a la integración latinoamericana. La diferencia es que en el primer caso se asegura que si Bolivia acepta su situación actual se logrará el acercamiento regional y ambos países podrán impulsar una "agenda de futuro"; mientras que en el segundo se dice que para que esto se cumpla es necesario que el país altiplánico tenga su propia salida al Pacífico. 


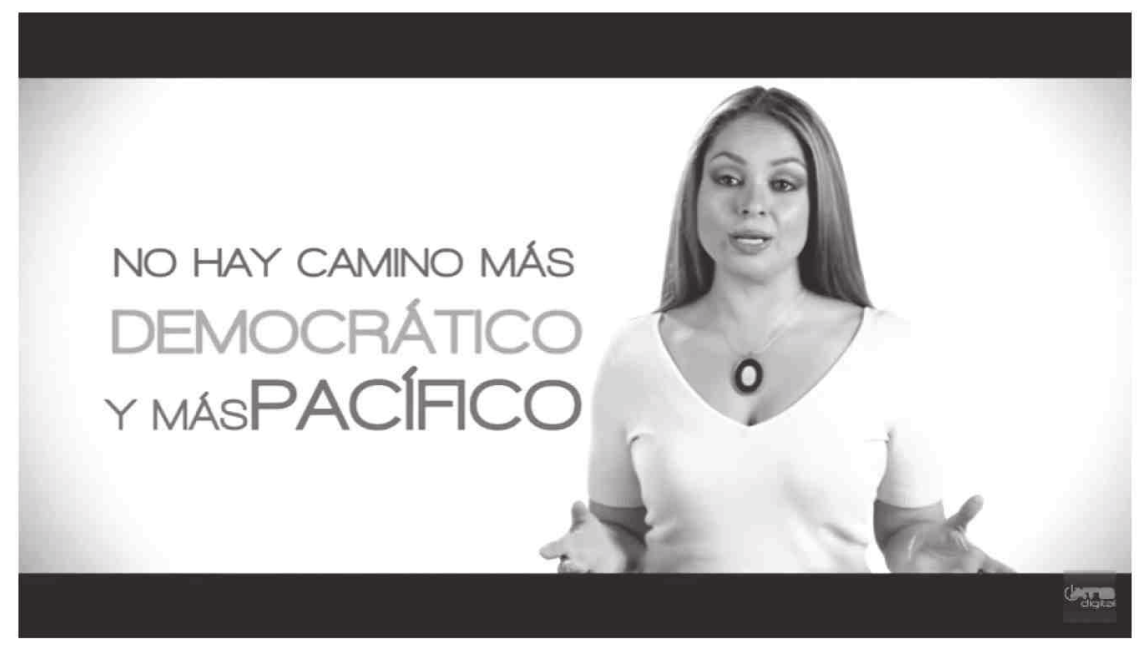

Demanda marítima de Bolivia ante la Corte Internacional de Justicia o "video del mar"

Figura 8. Demanda marítima de Bolivia ante la Corte Internacional de Justicia o "video del mar" (ATB Red Nacional, 2014).

La última imagen del "Video del mar" es categórica al afirmar que, "mientras exista" Bolivia hará "todo cuanto sea posible" para recuperar su soberanía.

\section{Conclusión: \\ Diplomacia pública como propuesta y solución}

Al revisar individualmente cada video podemos señalar, a partir del instrumento analítico y la caracterización según las culturas de anarquía, algunas estrategias compartidas por ambos gobiernos en el marco de la diplomacia pública mediada. Realizaremos el análisis partiendo por los sitios de representación anteriormente descritos, la producción y la imagen misma, para luego concluir la modalidad principal: la social.

Las similitudes en cuanto a la producción de ambos videos a partir de un montaje audiovisual pueden ser descritas como pulcros, serios y de acuerdo con los estándares actuales y profesionales. Así, técnicamente, la realización, unida a la composición, mirada desde el ordenamiento y presentación de las imágenes apuntan a comunicar posturas propositivamente. Esto queda de manifiesto en cuanto a la velocidad e intercalado de imágenes. Por tanto, el primer video en ser publicado -el chileno- y luego el segundo utilizan una producción de similares características técnicas y composicionales. 
En cuanto a la producción, resaltan grandes diferencias en la composición en donde el fondo blanco del video de Bolivia resalta en contraste con los paisajes del video chileno. Así también los protagonistas del video boliviano son personajes del pueblo; mientras que en el chileno autoridades y un funcionario del puerto aludido en el mensaje chileno, quien entrega cifras referentes a los beneficios aduaneros otorgados a Bolivia. Finalmente, en lo composicional, los mensajes contrastan bastante ya que estos pasan de ser informativos de base, para luego brindar argumentos persuasivos a partir de dos tipos de estrategias argumentales. El chileno, como se mencionó anteriormente, distancia el argumento a partir de la estadística y el legalismo, es racional en el abordaje. Por el contrario, el boliviano busca establecer un clima de emotividad en sus planteamientos, orientando la narrativa a partir de la reivindicación y oscilando entre la victimización y el contraataque.

Referente el sitio de la Imagen misma, lo que pretenden dar a entender en cada video es un hecho, sin duda, con argumentos divergentes. Ello corresponde a la discusiva que se conoce ampliamente, pero destaca que ambos presentan similitudes en cuanto a la imagen proyectada de respeto al derecho internacional y disposición hacia una región integrada. Desde las modalidades de lo técnico y composición, se observa en el caso chileno primero el tecnicismo estadístico y luego termina con el legalismo antes mencionado. Por el lado boliviano, la composición se impone por medio de relatos históricos de la relación para luego contraargumentar el legalismo chileno y cerrar el video describiendo lo que la demanda busca como resultado final. A continuación, se detalla esquemáticamente el análisis en la siguiente tabla 5 comparativa. 
Tabla 5

Comparación de la diplomacia pública mediada y relaciones bilaterales entre Bolivia y Chile

\begin{tabular}{|c|c|c|c|c|}
\hline \multirow[b]{2}{*}{$\begin{array}{l}\text { Análisis } \\
\text { visual } \\
\text { Dimensiones } \\
\text { DPM }\end{array}$} & \multicolumn{2}{|c|}{ Chile - Video Mito y realidad } & \multicolumn{2}{|c|}{ Bolivia - Video del mar } \\
\hline & Producción & Imagen misma & Producción & Imagen misma \\
\hline $\begin{array}{l}\text { Dirigido } \\
\text { a públicos } \\
\text { extranjeros }\end{array}$ & $\begin{array}{l}\text { 1) Comuni- } \\
\text { cación estilo } \\
\text { formal e ins- } \\
\text { titucional de } \\
\text { autoridades. } \\
\text { 2) Dirigido a } \\
\text { varios públi- } \\
\text { cos, incluso } \\
\text { interno. }\end{array}$ & $\begin{array}{l}\text { 1) Respetuoso } \\
\text { de los tratados } \\
\text { internacionales. } \\
\text { 2) Chile tiene } \\
\text { vocación de } \\
\text { paz. } \\
\text { 3) Integración } \\
\text { con Chile } \\
\text { beneficia al pue- } \\
\text { blo boliviano } \\
\text { 4) Ceder } \\
\text { soberanía es } \\
\text { intransable. }\end{array}$ & $\begin{array}{l}\text { 1) Voceros } \\
\text { ciudadanos } \\
\text { anónimos que } \\
\text { representan } \\
\text { diversidad } \\
\text { boliviana y la } \\
\text { unión. } \\
\text { 2) Dirigido a } \\
\text { responder al } \\
\text { video chileno, } \\
\text { sus públicos } \\
\text { son varios, in- } \\
\text { cluso internos. }\end{array}$ & $\begin{array}{l}\text { 1) Una aspiración } \\
\text { nacional, histórica } \\
\text { y de todos. } \\
\text { 2) La falta de una } \\
\text { salida al mar ex- } \\
\text { plica el subdesa- } \\
\text { rrollo boliviano. } \\
\text { 3) Chile fue inva- } \\
\text { sor y hoy engaña. } \\
\text { 4) Relativiza las } \\
\text { concesiones chile- } \\
\text { nas a Bolivia. } \\
\text { 5) No hay inte- } \\
\text { gración latinoa- } \\
\text { mericana sin una } \\
\text { salida soberana } \\
\text { al mar. } \\
\text { 6) Los logros } \\
\text { |políticos y } \\
\text { económicos de } \\
\text { Evo Morales son } \\
\text { presentados. }\end{array}$ \\
\hline
\end{tabular}




\begin{tabular}{|c|c|c|c|c|}
\hline \multirow[t]{2}{*}{$\begin{array}{l}\text { Estructura } \\
\text { narrativa y ar- } \\
\text { gumentación }\end{array}$} & $\begin{array}{l}\text { Ambientación } \\
\text { de oficinas } \\
\text { y paisajes } \\
\text { serenos de } \\
\text { la costa y un } \\
\text { puerto. }\end{array}$ & $\begin{array}{l}\text { "Generosidad" } \\
\text { por otorgar } \\
\text { privilegios de } \\
\text { acceso y uso de } \\
\text { modernos puer- } \\
\text { tos inigualables. }\end{array}$ & $\begin{array}{l}\text { Ambientación } \\
\text { de fondo blan- } \\
\text { co constante y } \\
\text { de impacto. }\end{array}$ & $\begin{array}{l}\text { Se explica que } \\
\text { Bolivia recurrió al } \\
\text { tribunal inter- } \\
\text { nacional porque } \\
\text { tiene "vocación de } \\
\text { paz". }\end{array}$ \\
\hline & $\begin{array}{l}\text { 1) Uso de } \\
\text { cifras y datos } \\
\text { para avalar } \\
\text { argumentos. } \\
\text { 2) Alarma a } \\
\text { partir de la } \\
\text { exageración. }\end{array}$ & $\begin{array}{l}\text { 1) Argumentos } \\
\text { racionales y } \\
\text { legales. } \\
\text { 2) Advierten } \\
\text { peligros y } \\
\text { consecuencias } \\
\text { al derecho } \\
\text { internacional } \\
\text { que suscita la } \\
\text { demanda boli- } \\
\text { viana. }\end{array}$ & $\begin{array}{l}\text { 2) Mensajes } \\
\text { simples y } \\
\text { claros para ge- } \\
\text { nerar empatía } \\
\text { en un público } \\
\text { masivo. }\end{array}$ & $\begin{array}{l}\text { 1) Argumentos } \\
\text { basados en la } \\
\text { emoción y en la } \\
\text { "justicia" de su } \\
\text { demanda. }\end{array}$ \\
\hline $\begin{array}{l}\text { Cultura de } \\
\text { anarquía }\end{array}$ & \multicolumn{2}{|c|}{ Locke - Competencia y rivalidad } & \multicolumn{2}{|c|}{ Hobbes - Ataque y confrontación } \\
\hline
\end{tabular}

Nota: Confección de los autores.

Finalmente, enfocamos el análisis a la modalidad social en donde, según nuestro parecer, los criterios de la diplomacia pública mediada pueden ser evidenciados de mejor forma. Esta entrada al análisis invierte el orden, ya que consideramos la relevancia principal de esta, desplazando los sitios de producción e imagen misma a un nivel secundario. En ambos videos se evidencia un esfuerzo de relatar sus planteamientos a públicos, aunque son ambiguos en ese objetivo. El video chileno presenta sus argumentos racionales a un público difuso que a veces pareciera ser una mezcla entre interno y externo. Sin embargo, luego el video es modificado meses después, y pareciera que el doblaje posterior al idioma inglés apuntaría a resolver la ambigüedad sobre su público meta. Por otra parte, el video boliviano sufre de una ambigüedad similar al chileno; no obstante, al no existir una versión doblada no pareciera que el gobierno boliviano anticipa necesitar de un video dirigido a públicos no hispanohablantes ni extra regionales. Por otra parte, el video boliviano sufre de otra ambigüedad mayor, intenta contestar al video chileno punto por punto. Esto, como estrategia se muestra como ataque y se contempla, en la mirada inicial de terceros, como una acción dirigida a las autoridades chilenas. Por último, el Video del mar, como respuesta, podría ser considerado en parte como una 
acción de diplomacia pública mediada, pero también simultáneamente opaca sus argumentos más fuertes por el estilo confrontacional.

Por otro lado, el segundo criterio de diplomacia pública mediada mencionado en la modalidad social implica instalar una estructura narrativa y de argumentación que permita proyectar una imagen basada en un esquema persuasivo y empático a integrantes de la opinión internacional. La estructura narrativa del video boliviano establece una contexto de historicidad que, a nuestro juicio, apela al apoyo de terceros al establecer roles de victimario y victima en una situación de injusticia que podría justiciar una ofensiva de parte del gobierno boliviano hacia las autoridades chilenas. En cambio, el video chileno, al proponer una situación narrativa de desmitificar con hechos concretos en cifras, pareciera difícil de activar en terceros la empatía necesaria para recibir el apoyo y defender los argumentos que propone. En conclusión, la estructura narrativa de Bolivia en el contexto de diplomacia pública mediada con base en lo que representa y los efectos que intenta propiciar, pareciera acercarse, de mejor manera, a los objetivos de la diplomacia pública.

En cuanto a la argumentación, en el video chileno se presenta una racionalidad y coherencia en sus planteamientos mayor que en el de Bolivia. Al cuantificar los beneficios otorgados por el tratado de 1904 a Bolivia, en gran medida establece un argumento que es razonable incluso persuasivo a públicos internacionales. Ahora bien, en ambos casos al sobrevalorar o tratar de desvirtuar los alcances del Tratado de 1904, se presentan argumentaciones problemáticas. Desde la perspectiva chilena, decir que de no respetar el Tratado todo el orden del derecho internacional estaría peligrando es exagerado. Mientras que, por el lado boliviano, decir que la situación no tiene que ver directamente con el Tratado es intentar desplazarlo de la centralidad de la disputa. Es decir, el Tratado y lo que establece este es justamente lo que ha venido provocando la situación tensa y de competencia entre ambos países durante más de un siglo. Estos argumentos falaces, por su explicitación sobredimensionada y a la luz del marco conceptual presentado, se alejan de entender las potencialidades de la diplomacia pública para acercar a sociedades a partir de virtudes y apertura hacia la cooperación entre naciones.

Finalmente, al considerar los hallazgos derivados de un análisis de los videos con base en los conceptos de la diplomacia pública mediada y utilizando la metodología visual, se podría, tentativamente, señalar, desde la mirada constructivista, que la relación bilateral entre Bolivia y Chile seguirá restringida por lógicas de interacción que se refieren a la cultura de anarquía tipo lockeana. Este tipo de cultura se mantiene al establecer y proponer una estructura narrativa macro de rivalidad y competencia por el apoyo en cuanto a la demanda.

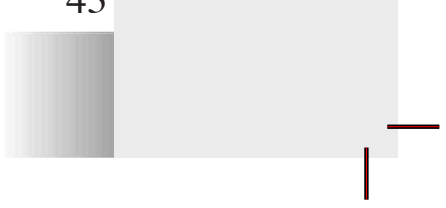


JULIO · DICIEMBRE · 2016 DANIELAGUIRREA ·JANCRISTÓBALVILLALOBOS

REVISTA 892

Ahora, por otra parte, desde lo argumental se estima que existiría, al menos retóricamente y primordialmente desde el lado boliviano, una tipificación mixta hobbesiana-lockeana al contraatacar directamente lo presentado en el video chileno, lo cual se distancia del propósito de la diplomacia pública mediada de interacción y atracción de terceros a partir de aspectos positivos proyectados a nivel internacional. $\mathrm{Y}$, a la vez, el contrataque conllevaría a activar al rival a la confrontación retórica en un principio, pero ciertamente imposibilitando un acercamiento futuro al ya haberse establecido y consolidado, aún más, la rivalidad y la cultura de anarquía que a esta caracteriza. 


\section{Referencias}

ATB Red Nacional. (2014). Demanda maritima de Bolivia ante la Corte Internacional de Justicia o "video del mar". Recuperado en https://www.youtube.com/ watch? $\mathrm{v}=\mathrm{t} 6 Z \mathrm{PCR}$ cltnQ.

Cull, N. J. (2008). Public Diplomacy before Gullion; the Evolution of a Phrase. In Snow, N. \& Taylor, P., The Routledge Handbook of Public Diplomacy, (pp.19-23).

Entman, R. M. (2004). Projections of power: Framing news, public opinion, and US foreign policy. University of Chicago Press.

Entman, R. M. (2008). Theorizing Mediated Public Diplomacy: The US Case. The International Journal of Press/Politics, 13(2), 87-102.

Fukuyama, F. (1989). The End of History? The National Interest, (16), 3-18.

Gilboa, E. (2008). Searching for a Theory of Public Diplomacy. The Annals of the American Academy of Political and Social Science, 616(1), 55-77.

Golan, G. J. (2013). Introduction: An Integrated Approach to Public Diplomacy. American Behavioral Scientist, 0002764213487711.

Golan, G. J. (2014). The Advertorial as a Tool of Mediated Public Diplomacy. International Journal of Communication, 8, 21.

Golan, G. J., \& Lukito, J. (2015). The Rise of the Dragon? Framing China”s Global leadership in Elite American Newspapers. International Communication Gazette, 77(8), 754-772.

Lacassagne, A. (2012), Cultures of Anarchy as Figurations: Reflections on Wendt, Elias and the English School. Human Figurations, 1(2),

Ministerio de Relaciones Exteriores de Chile. (2014). Chile y la aspiración marítima boliviana: mito y realidad. Recuperado de https:/www.youtube.com/ watch? $\mathrm{v}=\mathrm{iWiTV} 2$ TFAk

Nye, J. S. (1990). Soft Power. Foreign policy, (80), 153-171.

Nye, J. S. (2008). Public Diplomacy and Soft power. The Annals of the American Academy of Political and Social Science, 616(1), 94-109.

Rose, G. (2012). Visual Methodologies: An Introduction to Researching with Visual Materials. Thousand Oaks: Sage. 
JULIO · DICIEMBRE · 2016 DANIELAGUIRREA · JUANCRISTÓBALVILLALOBOS

Tuch, H. N. (1990). Communicating with the World: US Public Diplomacy Overseas. New York: Macmillan-St. Martin's Press.

Wendt, A. (1999). Social Theory of International Politics. Cambridge University Press. 